\title{
Prototype Sistem Informasi Pelayanan Bayi Baru Lahir pada Fasilitas Kesehatan Primer
}

\author{
Rinda Nurul Karimah*, Andri Permana Wicaksono \\ Jurusan Kesehatan \\ Politeknik Negeri Jember \\ Jember \\ *rindank6@gmail.com
}

\begin{abstract}
Abstrak-Pelayanan kesehatan untuk bayi baru lahir merupakan salah satu program kesehatan yang bertujuan untuk menjamin kelangsungan hidup dan tumbuh kembang anak secara optimal. Data Badan Pusat Statistik (BPS) pada tahun 2018 berdasarkan Survei Demografi Kesehatan Indonesia (SDKI) tahun 2017 menunjukkan Angka Kematian Bayi (AKB) di Indonesia masih tinggi yaitu mencapai 24 kematian setiap 1000 kelahiran hidup. Fasilitas kesehatan primer merupakan sarana pelayanan kesehatan tingkat pertama yang berperan sebagai tonggak pelayanan awal, yaitu menjadi gerbang pelayanan kesehatan tingkat lanjut terutama di era jaminan kesehatan nasional seperti saat ini. Penelitian ini merupakan penelitian kualitatif dengan metode desain sistem menggunakan model prototipe. Penerapan pedoman pelayanan kesehatan yang ditetapkan oleh Kementerian Kesehatan bagi pelayanan ibu dan bayi baru lahir di fasilitas kesehatan primer, memerlukan dukungan teknologi informasi berupa sistem informasi untuk mendukung kelengkapan data, sehingga informasi yang dihasilkan dapat lengkap. Hal ini disebabkan oleh adanya tuntutan kebutuhan informasi yang semakin meningkat, terutama terkait adanya permasalahan ketidaklengkapan data pada pelayanan klinis dan pelaporan bayi baru lahir. Hasil keluaran formulir bayi baru lahir dan surat keterangan kelahiran yang diinginkan oleh user telah terpetakan dan menjadi output dari desain prototipe, sehingga hasil desain prototipe dapat menjadi solusi dari permasalahan yang ada. Penelitian ini dilaksanakan selama tiga bulan, diawali dengan identifikasi kebutuhan, pembangunan prototipe dan diakhiri dengan evaluasi. Luaran yang dihasilkan berupa desain prototipe pendukung kelengkapan data pelayanan klinis bayi baru lahir untuk fasilitas kesehatan primer.
\end{abstract}

Kata Kunci: Pelayanan bayi baru lahir, Fasilitas Kesehatan Primer, Prototipe.

\section{Pendahuluan}

Bayi baru lahir merupakan kelompok masyarakat yang rentan dan perlu mendapat perhatian serius, karena masih tingginya Angka Kematian Bayi (AKB) di Indonesia. Angka Kematian Bayi Baru Lahir mencapai 2/3 dari total Angka Kematian Bayi [1]. Pelayanan kesehatan untuk bayi baru lahir merupakan salah satu program kesehatan yang bertujuan untuk menjamin kelangsungan hidup dan tumbuh kembang anak secara optimal. Hal ini dilakukan dalam rangka mewujudkan anak Indonesia yang sehat sebagai modal dasar bagi pembangunan bangsa. Hasil riset Badan Pusat Statistik (BPS) di tahun 2016 menunjukkan AKB masih tinggi yaitu mencapai 25,5 artinya ada sekitar 25,5 kematian setiap 1000 bayi lahir [2]. Angka kematian bayi pada tahun 2017 masih tinggi meskipun telah mengalami penurunan menjadi 24 kematian setiap 1000 kelahiran hidup. Data BPS tersebut berdasarkan Survei Demografi Kesehatan Indonesia (SDKI) tahun 2017

Bayi baru lahir memerlukan asuhan yang segera, cepat, tepat, aman dan bersih. Hal tersebut merupakan bagian esensial bayi baru lahir. Sebagian besar proses persalinan terfokus pada ibu, tetapi penatalaksanaan persalinan baru dikatakan berhasil jika ibu dan bayinya dalam kondisi keadaan sehat optimal. Fasilitas kesehatan primer merupakan sarana pelayanan kesehatan tingkat pertama yang berperan sebagai tonggak pelayanan primer, yaitu menjadi gerbang pelayanan kesehatan tingkat lanjut terutama di era jaminan kesehatan nasional saat ini. Bidan di fasilitas kesehatan primer diberi tanggung jawab penuh terhadap keselamatan ibu dan bayi pada persalinan normal dan beberapa saat sesudah selesainya persalinan. Bidan harus mengetahui dengan segera timbulnya perubahan pada bayi dan bila perlu memberikan pertolongan pertama seperti menghentikan perdarahan, membersihkan jalan napas, memberikan oksigen, dan melakukan pernapasan buatan sampai bayi tersebut mendapat perawatan yang memiliki perlengkapan yang lengkap serta perawatan yang baik, sampai pengawasan dan pengobatan yang dilakukan sebaik-baiknya [3]. Semua kegitan yang dilakukan memerlukan proses pencatatan terkait kebutuhan kelengkapan data untuk proses dokumentasi medis.

Adanya kejadian penculikan dan perdagangan bayi yang termasuk kriteria perdagangan orang (traficking in person) juga harus menjadi perhatian khusus dan menambah urgensi kebutuhan kelengkapan data pada pelayanan bayi baru lahir. Kejadian ini merupakan suatu tantangan bagi upaya peningkatan kualitas program kesehatan bayi baru lahir yang saat ini menjadi prioritas utama pembangunan kesehatan. Peningkatan jaminan keamanan, prosedur, dan kelengkapan data pada pelayanan bayi baru lahir diharapkan dapat mencapai target pemerintah untuk tidak terjadi lagi kasus penculikan dan perdagangan bayi baru lahir (zero toleran) di fasilitas pelayanan kesehatan [1]. 


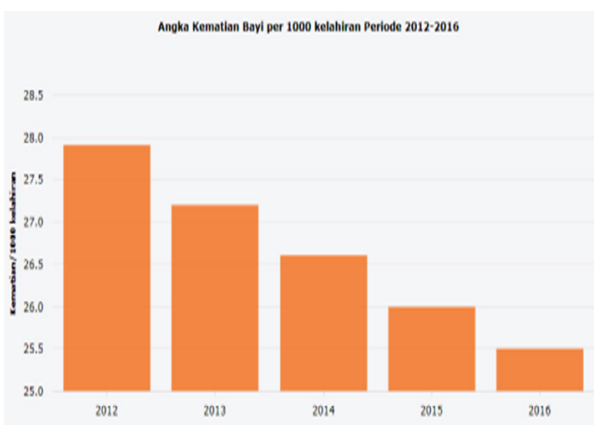

Gambar 1.Angka Kematian Bayi di Indonesia Periode 2012-2016

Perkembangan teknologi informasi saat ini sangat terasa manfaatnya dalam membantu permasalahan pada suatu proses kegiatan, tidak terkecuali di bidang pelayanan kesehatan. Hal ini disebabkan oleh adanya tuntutan kebutuhan informasi yang semakin meningkat, terutama terkait kelengkapan data untuk keperluan medis. Teknologi komputerisasi mempunyai kemampuan sebagai media komunikasi yang dapat mempercepat proses kerja manusia, mulai dari pencatatan data, pengolahan data sampai menjadi informasi dan pelaporan yang lengkap dan akurat.

Kementerian Kesehatan telah menetapkan berbagai Peraturan Menteri Kesehatan dan menyusun Pedoman Pelayanan Kesehatan bagi Ibu dan Bayi Baru Lahir di fasilitas kesehatan primer dan bidan jejaring. Pedoman tersebut dipergunakan sebagai acuan bagi tenaga kesehatan dalam memberikan pelayanan, salah satunya terkait Pedoman Asuhan Bayi Baru Lahir yang mengatur standar pelayanan yang bersifat teknis medis. Langkahlangkah kegiatannya berupa: 1) Pendataan bayi baru lahir; 2) Pelayanan kesehatan bayi baru lahir; 3) Pengisian dan pemanfaatan Buku KIA; 4) Pencatatan dan pelaporan; 5) Rujukan pertolongan kasus komplikasi pada bayi baru lahir jika diperlukan [4]. Penerapan standar tersebut memerlukan dukungan teknologi informasi untuk mendukung kelengkapan data, sehingga informasi yang dihasilkan dapat akurat. Keakuratan informasi akan berdampak pada peningkatan keamanan dan kualitas pelayanan medis serta fungsi medikolegal.

Berdasarkan latar belakang tersebut, peneliti mengusulkan solusi permasalahan kebutuhan kelengkapan data dengan membuat perancangan prototipe pendukung kelengkapan data pelayanan klinis bayi baru lahir untuk fasilitas kesehatan primer.

\section{Metode}

\section{a. Jenis Penelitian}

Jenis penelitian ini adalah kualitatif dengan model perancangan sistem menggunakan prototyping model, yaitu model perancangan yang cepat dan pengujian terhadap model kerja (prototipe) dari aplikasi baru melalui proses interaksi dan berulang-ulang yang biasa digunakan ahli sistem informasi dan ahli bisnis [5]. Dengan metode prototyping ini pengembang dan pengguna (user) dapat saling berinteraksi selama proses pembuatan sistem [3] Model prototipe pada penelitian ini terdiri dari langkah sebagai berikut:
1. Pengumpulan kebutuhan/identifikasi kebutuhan

2. Membangun prototyping

3. Evaluasi prototyping

\section{b. Lokasi Penelitian}

Penelitian ini dilakukan selama 3 (tiga) bulan yaitu dari bulan Agustus sampai Oktober 2017 di Klinik Sakinah Kaliurang, yaitu salah satu FKTP di Kabupaten Jember yang memiliki keanggotaan kapitasi peserta BPJS mencapai 600 orang dan memiliki 2 orang bidan satu atap dan 3 bidan jejaring yang tersebar di wilayah Kecamatan Sumbersari.

\section{c. Unit Analisis}

Unit analisis pada penelitian ini adalah seluruh bidan yang bertugas melaksanakan pelayanan bayi baru lahir di FKTP klinik Sakinah Kaliurang Jember. Terdapat lima orang bidan (dua orang bidan satu atap dan tiga bidan jejaring yang tersebar di wilayah Kecamatan Sumbersari).

\section{d. Teknik Pengumpulan Data}

Teknik pengumpulan data yang digunakan dalam penelitian ini meliputi observasi, wawancara, dan diskusi. Analisis data dilakukan secara kualitatif dengan mengeksplorasi pengetahuan para bidan yang diperoleh melalui wawancara dan diklarifikasi dengan hasil observasi. Hasil tersebut kemudian dilakukan diskusi dan dikombinasi dengan referensi terkait regulasi yang berlaku dari Kemenkes RI untuk memperoleh kesimpulan terkait kebutuhan pembangunan prototipe.

\section{Hasil}

Hasil dari penelitian ini akan dilakukan tiga langkah model desain sistem prototipe, yaitu:

1. Tahap pengumpulan kebutuhan/identifikasi kebutuhan diperoleh hasil kebutuhan responden terkait dukungan saat pelaksanaan pelayanan klinis bayi baru lahir berupa kewaspadaan umum (universal precaution) saat penilaian awal sebelum bayi lahir dan segera setelah bayi baru lahir. Dukungan yang dibutuhkan berupa alur tindakan terorganisir sebagai implementasi MTBS (Manajemen Terpadu Balita Sakit) dan kebutuhan keseragaman formulir terkait instrumen penangkapan kelengkapan data serta terkait legalitas dari pendokumentasian yang dilakukan termasuk pengeluaran surat keterangan kelahiran.

2. Tahap membangun/pengembangan prototyping, pada tahap ini dihasilkan Data Flow Diagram (DFD) dan Entity Relation Diagram (ERD) Prototipe pendukung kelengkapan data pelayanan klinis bayi baru lahir di fasilitas kesehatan primer.

3. Evaluasi protoptyping, hasil evaluasi yang diperoleh adalah rancangan DFD dan ERD pada tahap sebelumnya dapat diterima oleh user kemudian disajikan dalam interface sistem.

\section{Diskusi}

\section{a. Identifikasi Kebutuhan}

Identifikasi kebutuhan yang dimaksud adalah kebutuhan terhadap prototipe pendukung kelengkapan 
data pelayanan klinis bayi baru lahir untuk fasilitas kesehatan primer. Pengambilan data melalui kegiatan observasi, wawancara, dan diskusi dengan klinisi pelaksana pelayanan klinis bayi baru lahir di fasilitas kesehatan primer dalam hal ini khususnya klinisi di klinik Sakinah Kaliurang dan bidan jejaringnya. Terdapat 5 orang responden pada penelitian ini yaitu 2 orang bidan satu atap dan 3 bidan jejaring.

Hasil kesimpulan wawancara yang diperoleh dikombinasikan dengan referensi terkait regulasi yang berlaku dari Depkes yaitu Peraturan Menteri Kesehatan Republik Indonesia Nomor 53 Tahun 2014 Tentang Pelayanan Kesehatan Neonatal Esensial pasal 4 ayat 2 tentang pelayanan neonatal esensial 0 (nol) sampai 6 (enam) jam meliputi:

1) Menjaga bayi tetap hangat;

2) Inisiasi menyusu dini;

3) Pemotongan dan perawatan tali pusat;

4) Pemberian suntikan vitamin $\mathrm{k} 1$;

5) Pemberian salep mata antibiotik;

6) Pemberian imunisasi hepatitis b0;

7) Pemeriksaan fisik bayi baru lahir;

8) Pemantauan tanda bahaya;

9) Penanganan asfiksia bayi baru lahir;

10) Pemberian tanda identitas diri;

11) Merujuk kasus yang tidak dapat ditangani dalam kondisi stabil, tepat waktu ke fasilitas pelayanan kesehatan yang lebih mampu [7].

Hal tersebut juga sesuai dengan regulasi yang terdapat pada panduan pelayanan kesehatan neonatal essensial, sehingga disimpulkan kebutuhan data yang diperlukan terkait pengembangan prototipe pendukung kelengkapan data pelayanan klinis bayi baru lahir untuk fasilitas kesehatan primer berupa bagan alur manajemen bayi baru lahir yang terbagi menjadi bayi baru lahir normal dan bayi baru lahir dengan asfiksia. Asuhan bayi baru lahir dan tindakan penilaiannya. Selain itu juga formulir panduan pemeriksaan fisik yang dilakukan pada bayi baru lahir, formulir bayi baru lahir, dan penerbitan surat keterangan lahir.

Hasil keluaran formulir bayi baru lahir dan surat keterangan kelahiran yang diinginkan oleh user telah terpetakan dan menjadi output dari desain prototipe. Formulir tersebut berisi data-data pelayanan secara lengkap dan terstruktur disertai otentifikasi legalitas terdiri dari pemberi layanan, penerima layanan, dan saksi.

\section{b. Mengembangkan Prototipe}

Pengembangan prototipe dilakukan dengan mapping kebutuhan data terkait pelayanan klinis bayi baru lahir yang telah diperoleh pada tahap sebelumnya (tahap identifikasi kebutuhan), kemudian membuat mekanisme inferensi untuk mendeteksi kebutuhan pelayanan. Sistem pendukung operasional yang dihasilkan nantinya dapat menghasilkan bermacam produk informasi baik untuk pengguna internal maupun pengguna eksternal [8]. Pengguna internal pada prototipe yang dikembangkan ini adalah tenaga kesehatan terkait pelayanan bayi baru lahir, sedangkan pengguna eksternal merupakan pasien, keluarga pasien dan pihak ketiga. Tahap ini dihasilkan Data Flow Diagram (DFD) (Gambar 2)

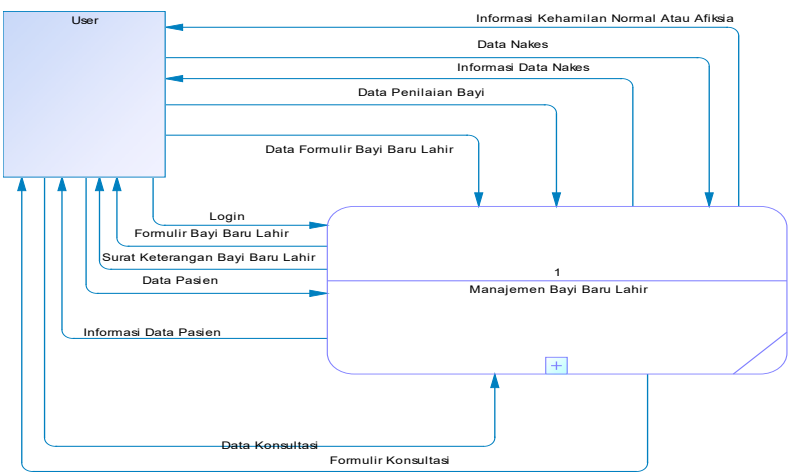

Gambar 2. DFD Level 0 Prototipe Pendukung Kelengkapan Data Pelayanan Klinis Bayi Baru Lahir

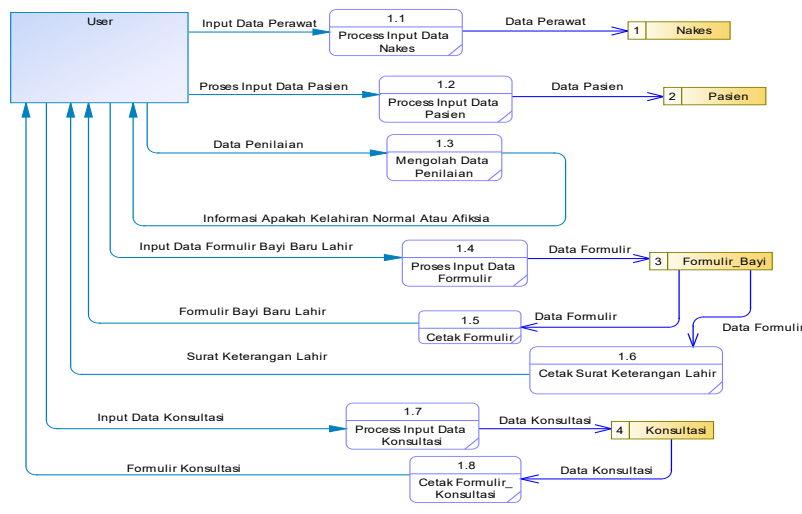

Gambar 3. DFD Level 1 Prototipe Pendukung Kelengkapan Data Pelayanan Klinis Bayi Baru Lahir

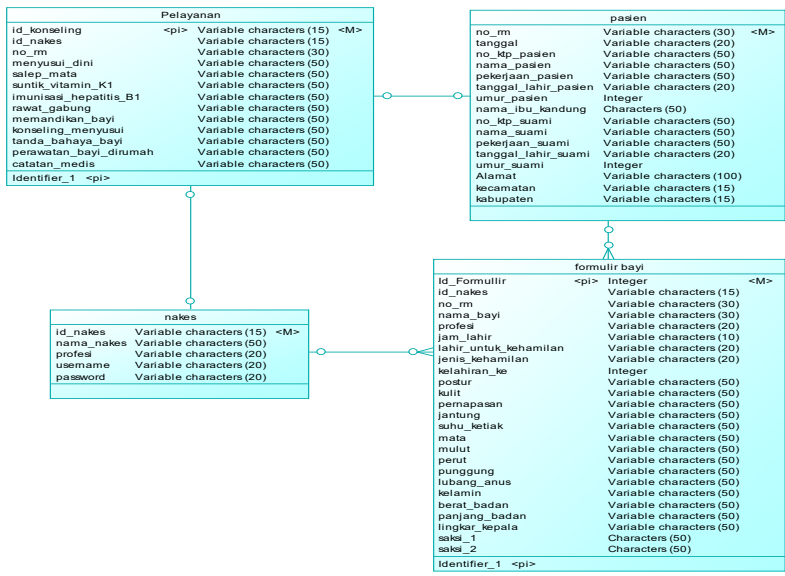

Gambar 4. ERD Prototipe Pendukung Kelengkapan Data Pelayanan Klinis Bayi Baru Lahir

DATA PASIEN

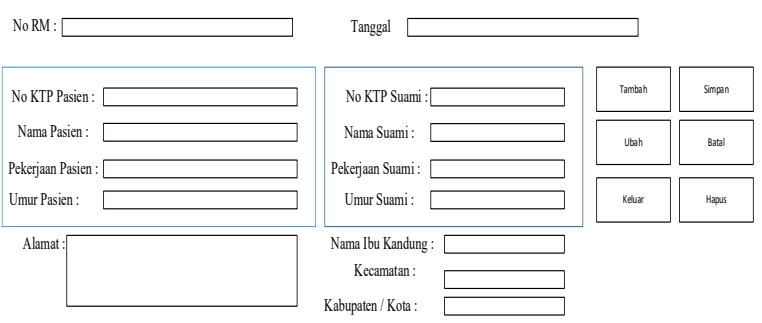

Gambar 5. Interface Data Pasien 


\section{DATA NAKES}

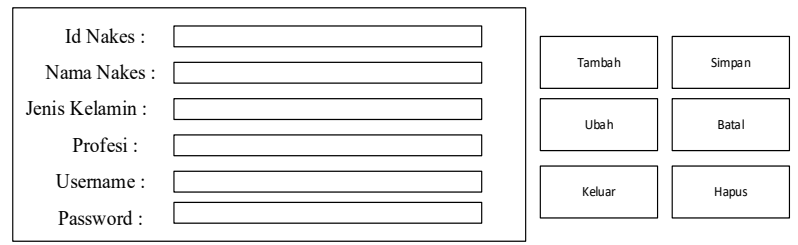

Gambar 6. Interface Data Nakes

Formulir Bayi Baru Lahir

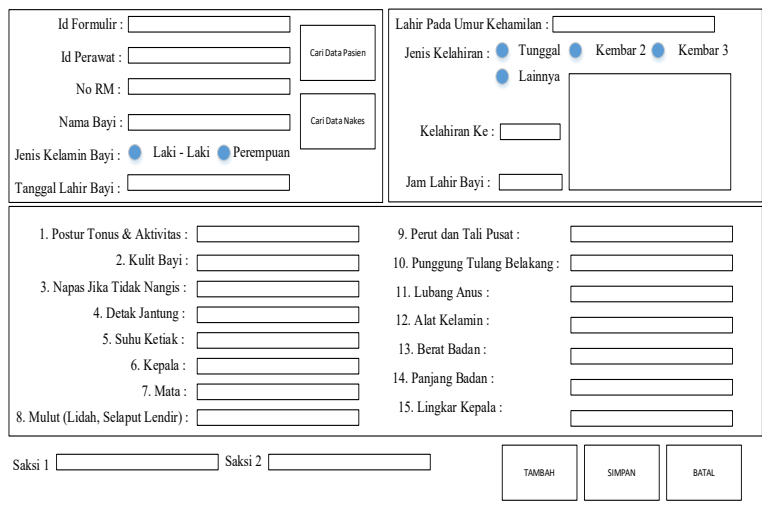

Gambar7. Interface Inputan Formulir Bayi Baru Lahir FORMULIR KONSULTASI BAYI
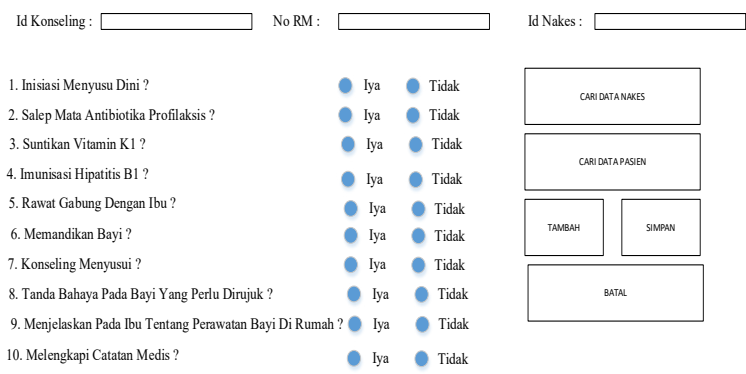

Gambar 8. Interface Inputan Formulir Konsultasi Bayi

PENILAIAN BAYI LAHIR NORMAL ATAU ASFIKSIA

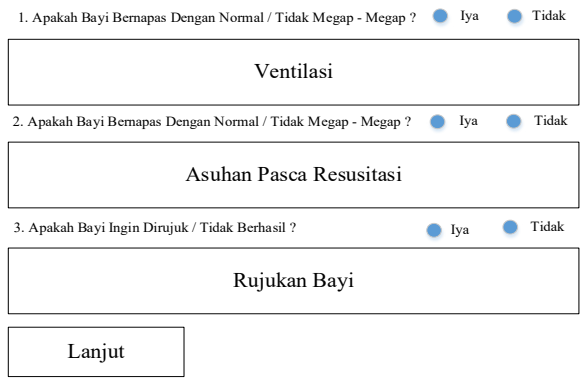

Gambar 9. Interface Inputan Penilaian bayi Form 1

Diagram alir data adalah teknik grafik yang digunakan untuk menjelaskan aliran informasi dan transformasi data dari masukan hingga keluaran [4]. DFD level 0 atau biasa juga disebut diagram konteks merupakan gambaran bagaimana sistem berinteraksi dengan eksternal entity, dalam hal ini yaitu user yang terdiri dari bidan pelaksana kegiatan terkait pelayanan klinis bayi baru lahir di fasilitas kesehatan primer.

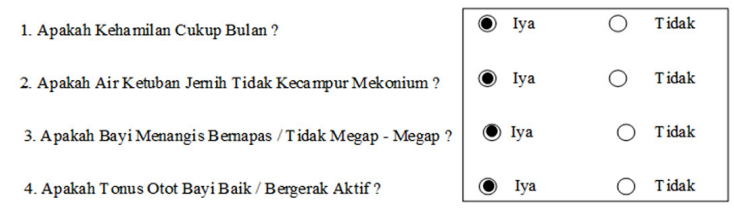

KETERANGAN BAYI LAHIR DENGAN NORMAL

Gambar 10. Interface Inputan Penilaian bayi Form 2 dan Keterangan Hasil

\section{FORMULIR BAYI BARU LAHIR}

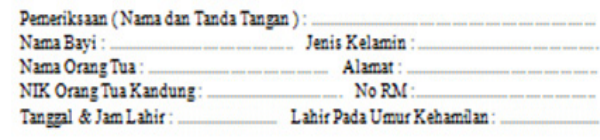

\begin{tabular}{|c|c|c|}
\hline PEMERIKSAAN & $\frac{\text { Tanggal }_{\text {Hasil }}}{\text { Ham }}$ & $\frac{\text { Tauggal }_{\text {Hasil }} \text { Jam }}{\text { Hons }}$ \\
\hline 1. Postur, torus, dan alivitas & & \\
\hline 2. Kulit bayi & & \\
\hline $\begin{array}{l}\text { 3. Permaparin ketila bayisedang } \\
\text { tidak menangis. }\end{array}$ & & \\
\hline 4. Detak jantung & & \\
\hline 5. Suhu ketiak & & \\
\hline 6. Kepala & & \\
\hline 7. Nata & & \\
\hline 8. Mulut (lidah selagutlendis) & & \\
\hline 9. Perut dan tali pwat & & \\
\hline 10. Pungmung tulang belakang & & \\
\hline 11. Lubang anus. & & \\
\hline 12. Alat kelamin & & \\
\hline 13. Berat badan & & \\
\hline 14. Panjang badan. & & \\
\hline 15. Lingiarkepala & & \\
\hline ASUHAN / KONSELING & $\begin{array}{l}\text { Walfu (tangga, jam) dilarulisn } \\
\text { asuban }\end{array}$ & Keterangan \\
\hline 1. Inisiasi menyusuidiri. & & \\
\hline $\begin{array}{l}\text { 2. Salep mata antibiotica } \\
\text { profilaksis. }\end{array}$ & & \\
\hline 3. Suntukan viamin $K 1$ & & \\
\hline 4. Inunisasi bepatris B1. & & \\
\hline 5. Rawat groung dengn ibu. & & \\
\hline 6. Memandikan bayi & & \\
\hline 7. Ronseling menyusui & & \\
\hline $\begin{array}{l}\text { 8. Tanda - tanda bahaya pada } \\
\text { bayi yang perlu dirsjuk }\end{array}$ & & \\
\hline $\begin{array}{l}\text { 9. Menjelasican pada boutening } \\
\text { perawatan bayi dirumah }\end{array}$ & & \\
\hline 10. Aelengrapi catatn madis. & & \\
\hline 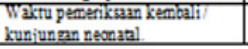 & Tangel & Tangal . \\
\hline
\end{tabular}

Nams Orang Tua Kandung Salsi Penolong Persalinan
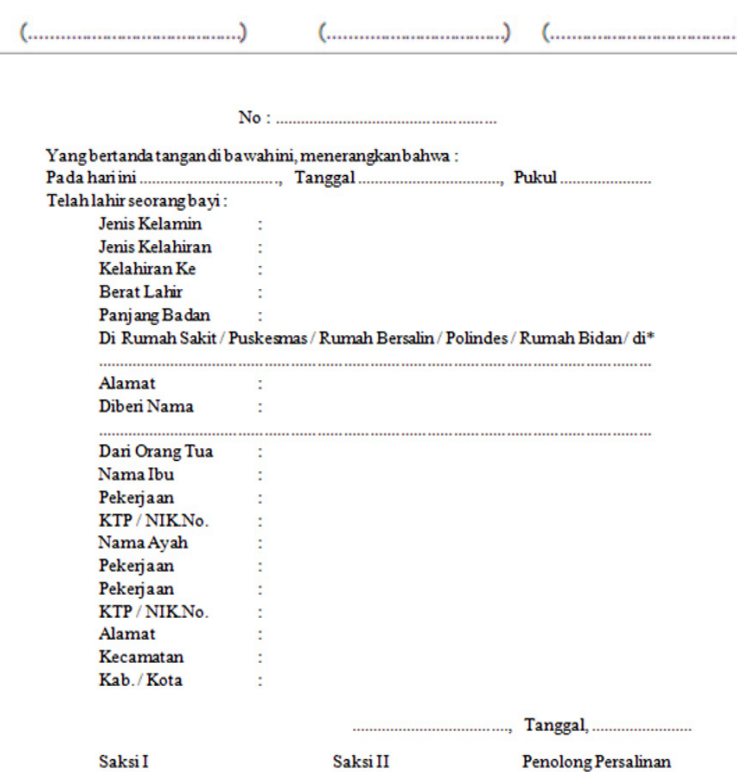

Gambar11.Output Formulir dan Surat Keterangan Lahi 
DFD level 1 (gambar 3) menunjukkan penjabaran lebih rinci dari DFD level 0 terakit masukan-proses dan keluaran pada sistem pendukung kelengkapan data pelayanan klinis bayi baru lahir. DFD dalam bahasa Indonesia disebut sebagai DAD (Data Arus Data) memperlihatkan gambaran tentang masukan-proseskeluaran dari suatu sistem/perangkat lunak, kemudian ditransformasi oleh elemen-elemen pemprosesan dan objek-objek data mengalir ke dalam perangkat lunak, kemudian ditransformasi oleh elemen-elemen pemprosesan, dan objek-objek data hasilnya akan mengalir keluar dari sistem atau perangkat lunak [6].

Gambar 4 menunjukkan desain Entity Relation Diagram (ERD) Prototipe Pendukung Kelengkapan Data Pelayanan Klinis Bayi Baru Lahir di FKTP. ERD adalah suatu model jaringan kerja (network) yang menguraikan susunan data yang disimpan dari sistem secara abstrak [9]. Gambar ERD berikut menjelaskan hubungan antardata dalam basis data yang mempunyai hubungan antarrelasi yaitu antara entitas nakes (tenaga kesehatan) dalam hal ini bidan atau dokter penanggung jawab pelaksana pelayanan dengan entitas pasien, pelayanan, dan formulir bayi.

\section{c. Evaluasi Prototipe}

Hasil dari pengembangan prototipe berupa DFD dan ERD dievaluasi untuk mengetahui apakah dapat diterima oleh user. Userpada penelitian ini adalah responden yang akan menggunakan aplikasi hasil operasional dari prototipe yang dikembangkan. Evaluasi dilakukan melalui kegiatan diskusi kembali dengan para responden yaitu bidan pelaksana pelayanan klinis bayi baru lahir. Hasil evaluasi yang diperoleh adalah rancangan DFD dan ERD dapat diterima oleh responden. DFD dan ERD yang telah diterima tersebut kemudian dilanjutkan dengan penyajian dalam bentuk gambaran desain interface (tampilan antar muka) sistem (Gambar 5)

Interface data pasien ditunjukkan pada gambar 5 yang berisi data sosial pasien dan pemberian nomor rekam medis serta tanggal pelayanan.

Inteface data tenaga kesehatan ditunjukkan pada gambar 6, di mana untuk tenaga kesehatan yang dimaksud adalah terdiri dari menu isian profesi bidan atau dokter yang memberi pelayanan.

Interface inputan data formulir bayi baru lahir ditunjukkan pada gambar 7, di mana berisi informasi detai terkait data sosial dan kondisi klinis bayi berdasarkan hasil pemeriksaan secara objektif. Sedangkan interface inputan formulir konsultasi bayi disajikan pada gambar 8, di mana disediakan menu opsi pilihan ya dan tidak sesuai dengan pelayanan yang telah diberikan. Pada interface ini juga disediakan menu pencarian data baik data nakes maupun data pasien, hal ini ditujukan untuk memudahkan dengan pencarian kembali dari data base hasil input pada gambar 5 dan 6.

Interface inputan formulir penilaian bayi disajikan pada gambar 9, di mana pada interface ini user dituntun dengan arahan tindakan sesuai prosedur terkait dengan pilihan kondisi klinis dari bayi baru lahir.

Lanjutan dari arahan tindakan berupa item pertanyaan terkait penilaian bayi dengan hasil akhir menu berupa tampilan keterangan bayi, apakah bayi lahir dengan kondisi normal atau disertai asfiksia. Contoh tampilan penilaian dengan hasil akhir keterangan bayi lahir dengan normal nampak pada gambar 10 Selain itu output berupa cetak formulir terdiri dari formulir bayi baru lahir dan formulir surat keterangan lahir (Gambar 11).

\section{Kesimpulan}

Hasil penelitian dan pembahasan yang diperoleh dapat disimpulkan yaitu hasil perancangan prototipe secara keseluruhan dapat dikatakan berhasil, karena telah dapat diterima oleh user. Hal ini sesuai dengan kebutuhan dari nakes pemberi pelayanan pada bayi baru lahir di fasilitas kesehatan primer terkait permasalahan kebutuhan kelengkapan data untuk pelayanan klinis bayi baru lahir di fasilitas kesehatan primer. Saran dari peneliti, diharapkan hasil rancangan prototipe ini dapat dilanjukan ke tahap selanjutnya yaitu digunakan dalam operasional sehingga dihasilkan aplikasi kelengkapan data untuk pelayanan klinis bayi baru lahir di fasilitas kesehatan primer.

\section{Daftar Pustaka}

[1] Direktorat Kesehatan Anak Khusus, Panduan Pelayanan Kesehatan Bayi Baru Lahir Berbasis Perlindungan Anak. KEMENKES, Jakarta, 2010,

[2] Badan Pusat Statistik, Angka Kematian Bayi, BPS Jakarta, 2018.

[3] Djauhari T, Assegaff S, 2016. Perancangan Sistem Informasi Layanan Persidangan Pada Pengadilan Negeri Sengeti. Jurnal Manajemen Sistem Informasi Vol. 1 No. 1, September 2016.

[4] Mulyanto agus, 2009. Sistem Informasi Konsep dan Aplikasi. Pustaka Pelajar.

[5] Setiawan, Prototipe Sistem Informasi Inventori Dengan Pendekatan Berorientasi Objek, Jurnal Letera ICT, Vol.3 No.1, Mei 2016

[6] Nurhasanah Mey, dkk, Asuhan Kebidanan Pada Bayi Baru Lahir Fisiologis Di BPM Bidan Cucu Hudami, Amd.Keb Kabupaten Ciamis, Jurnal STIKES CIAMIS, 2015.Availablefrom:http://www.ejournal.stikesmucis.ac.id/ file.php? file $=$ preview_mahasiswa\&id $=1067 \& c-$ $\mathrm{d}=0 \mathrm{~b} 2173 \mathrm{ff} 6 \mathrm{ad} 6 \mathrm{a} 6 \mathrm{fb} 09 \mathrm{c} 95 \mathrm{f} 6 \mathrm{~d} 50001 \mathrm{df} 6 \&$ name $=$ 13DB277070.pdf

[7] KEMENKES RI, Buku Kesehatan Ibu dan Anak. Kementrian Kesehatan RI dan JICA. Jakarta, 2016.

[8] O’Brien, A. James, Marakas, George.M, Management Information System, 10th Edition McGraw-Hill/Irwin, New York, 2010.

[9] Yuhendra, Eko Yulianto R, 2015. Rekayasa Perangkat Lunak Pengolahan Data Distribusi Obat-obatan di PT. Anugrah Pharmindo Lestari Berbasis WEB. Jurnal Momentum, Vol. 17 No. 2, Agustus 2015. 